\title{
Correction to: First Epileptic Seizure and Initial Diagnosis of Juvenile Myoclonus Epilepsy (JME) in a Transcranial Direct Current Stimulation (tDCS) Study- Ethical Analysis of a Clinical Case
}

\author{
Anna Sierawska (D) Vera Moliadze • \\ Maike Splittgerber • Annette Rogge • \\ Michael Siniatchkin • Alena Buyx
}

Published online: 29 September 2021

(C) The Author(s) 2021

Correction to: Neuroethics (2020) 13:347-351

https://doi.org/10.1007/s12152-020-09444-6

The article First Epileptic Seizure and Initial Diagnosis of Juvenile Myoclonus Epilepsy (JME) in a Transcranial Direct Current Stimulation (tDCS) Study- Ethical Analysis of a Clinical case, written by Anna Sierawska, Vera Moliadze, Maike Splittgerber,

The online version of the original article can be found at https://doi.org/10.1007/s12152-020-09444-6

A. Sierawska $(\bowtie) \cdot$ A. Buyx

Institute for History and Ethics in Medicine, Medical School, Technical University of Munich, Ismaninger

Strasse 22, 81675 Munich, Germany

e-mail: anna.sierawska@tum.de

V. Moliadze $\cdot$ M. Splittgerber Institute of Medical Psychology and Medical Sociology, University Medical Center Schleswig Holstein, Kiel University, Kiel, Germany

\section{A. Rogge}

Division of Biomedical Ethics, Institute of Experimental Medicine, Kiel University, Kiel, Germany
Annette Rogge, Michael Siniatchkin and Alena Buyx, was originally published Online First without Open Access. After publication in volume 13, issue 3, pages 347-351 the author decided to opt for Open Choice and to make the article an Open Access publication. Therefore, the copyright of the article has been changed to (C) The Author(s) 2021 and the article is forthwith distributed under the terms of the Creative Commons Attribution 4.0 International License, which permits use, sharing, adaptation, distribution and reproduction in any medium or format, as long as you give appropriate credit to the original author(s) and the source, provide a link to the Creative Commons licence, and indicate if changes were made. The images or other third party material in this article are included in the article's Creative Commons licence, unless indicated otherwise in a credit line to the material. If material is not included in the article's Creative Commons licence and your intended use is not permitted by statutory regulation or exceeds the permitted use, you will need to obtain

M. Siniatchkin

Clinic for Child and Adolescent Psychiatry

and Psychotherapy, Medical Center Bethel, Bielefeld,

Germany 
permission directly from the copyright holder. To view a copy of this licence, visit http://creativecommons. org/licenses/by/4.0/. Open access funding enabled and organized by Projekt DEAL.

Open Access This article is licensed under a Creative Commons Attribution 4.0 International License, which permits use, sharing, adaptation, distribution and reproduction in any medium or format, as long as you give appropriate credit to the original author(s) and the source, provide a link to the Creative Commons licence, and indicate if changes were made. The images or other third party material in this article are included in the article's Creative Commons licence, unless indicated otherwise in a credit line to the material. If material is not included in the article's Creative Commons licence and your intended use is not permitted by statutory regulation or exceeds the permitted use, you will need to obtain permission directly from the copyright holder. To view a copy of this licence, visit http://creativecommons.org/licenses/by/4.0/.

Publisher's Note Springer Nature remains neutral with regard to jurisdictional claims in published maps and institutional affiliations. 